\title{
Does work influence women's autonomy or does autonomy deliberate women to work?
}

\author{
Ruskin Ristiana ${ }^{1}$ and Dwini Handayani ${ }^{2, *}$ \\ ${ }^{1}$ Master Program in Population and Labor Economics, Faculty of Economics and Business, \\ Universitas Indonesia, Depok, Indonesia \\ ${ }^{2}$ Faculty of Economics and Business, Universitas Indonesia, Depok, Indonesia
}

\begin{abstract}
Work, especially paid work, has been assumed to enhance women's autonomy, particularly their household autonomy. However, this assumption does not work in one causal direction. The causality relationship works both ways, that women work due to their high level of autonomy, but also because their employment status will increase their autonomy. The aim of this study is to understand the relationship between women's work status and their household autonomy. This study used data from the Indonesian Demography and Health Survey 2012, together with a multinomial logistic regression analysis on married women's work status and autonomy as dependent and independent variables, respectively. It was found that work status influences married women's household autonomy and vice versa. However, the direction and strength of the influence depend on the type of work status and autonomy.
\end{abstract}

\section{Introduction}

The relationship between work and women's autonomy has been discussed in the context of both economy and gender relations. Studies have shown that work status plays a significant role in women's autonomy [2], [7], [15], [6], and [17]. Work, primarily paid work, has been proven to increase women's autonomy [15] and [6]. The importance of work to increase women's autonomy is also reinforced by the United Nations, which emphasized increased work opportunities as an important means for women to achieve greater control over their lives. However, employment alone is not enough to increase women's autonomy because the influence of work on autonomy also depends on work characteristics and the dimension of autonomy [2], [5] and [6].

It is clear that employment plays an important role in women's autonomy. Work,

*Corresponding author: dwiniarianto@yahoo.com 
particularly paid work, can improve women's autonomy. However, the use of labor force participation as a proxy of women's autonomy has been criticized because many incidents have shown that a change in labor force participation does not directly improve women's autonomy. In contrast, employment status is associated with decreasing autonomy because work is used as a tool to fulfill economic needs rather than for self-actualization [10]. Autonomy is one tool to ensure women to be able to participate in the development of their selves, family and their community. The Sustainable Development Goals (SDGs) that has been launched stated that nobody left behind. That means that women must also be able to be involved in every decisions in their lives in this case "equipped with autonomy". Without autonomy they will always depend on other with will hinder their active participation in their daily lives and their community.

In Indonesia, most of the population adhere to patriarchal norms. In a patriarchal culture, women's autonomy is generally low [3]. A male's power provides justification that men have superiority and control over women [11]. The husband's role as the head and the main decision maker in the household also includes to determine a woman's role in the household. Thus, whether women have autonomy due to their job, or the contrary, becomes even more questionable. Based on the previous explanation, this study aims to examine the relationship between women's work status and their household autonomy. Does women's household autonomy influence their decision to work?

\section{Literature review}

Women's autonomy is considered important in development because it positively influences demographic behavior and provides outcomes such as women's participation in the labor market, contraceptives use, fertility, better child welfare, and others [3], [7], [16], [17] and [18]. There are various definition and conceptualization of women's autonomy. Women's autonomy may be defined as the ability of women to make strategic life choices, organize themselves to increase independence, and control resources to help them eliminate their subordination [5], [15], [16] and [18]. Women's autonomy may also be defined as the ability of women to affect decisions related to themselves and their nearest household members, the ability to control economic and information resources, and the ability to move freely [3]. For women, having such control is viewed as the key to improve their living conditions [4].

Women's autonomy is difficult to be consistently measured because it is a process and its nature is multidimensional [3] and [16]. The multidimensional aspect of women's autonomy indicates that there are several types of autonomy. Participation in decision making in the household and freedom of movement are often used as indicators of women's autonomy [5], [11], [6] and [18]. Decision making in the household is divided into two spheres: traditional (related to child care) and non-traditional (such as to manage household finances). Another indicator of women's lives that is important to the concept of autonomy is the authority in mobility; it defines the extent to which women can freely move or to be mobile outside their home. There are some widely used measurement of autonomy, such as freedom from violence in addition to participation in decision making, freedom of movement, and access and control to the economic resources in the household. [6], [11], [14] and [19].

The relationship between employment and women's autonomy has been recognized in terms of both economy and gender relations [5]. Work, especially paid work, has been proven to increase women's autonomy [5] and [6]. Theoretically, work and wages increase women's bargaining power in their homes because a woman who has her own income is able to take better care of herself and becomes less dependent on her husband or another person to survive. Her ability to negotiate increases because she holds stronger bargaining 
power in her house, and she is considered autonomous because she has greater control over herself and her family. Women that in the traditional society are perceived as homemakers have no authority in participating in decision making and also participating in income generating activities. Women are lacking behind in access that enable them and usually left behind. Left behind in empowerment. Women then becomes vulnerable with no equal right to economic resources, access to basic needs and ownership to property and inheritance. That hinder the achievement of the SDGs goal 1: End poverty in all its form.

In addition to work status, the type of work and the contribution to household income also affect women's household autonomy [5] and [6]. The contribution of women's wages to their family, especially if the contribution is large, can make them become more valuable in their household and, thus, hold higher bargaining power. Where or for whom women work also affects their autonomy. Women who work outside home or for others and not for their families have more opportunity to interact in the public sphere and with non-family members relative to women who work for their families or inside their homes. Similar to working for families, working at home usually prevents autonomy because doing so means that women are still under control of other family members and has less autonomy and mobility [5] and [6]. Women who have autonomy also work voluntarily and not out of necessity. They tend to choose paid work [12]. They negotiate with their spouses, possibly by offering to contribute to the household income but also still carry out their household responsibilities [8] and [9].

\section{Research methods}

This study uses data from the Indonesian Demographic and Health Survey 2012 (SDKI 2012), which collected basic information of household members and their living conditions among women aged 15-49 years old. The unit analysis of this study is married women living with their spouses $(30,142$ women) using the multinomial regression model.

This study defines economic autonomy as to have access to and control over economic resources. The women's answers to the two questions regarding the economic autonomy variables are then added to result in a total score of 0 if they are not completely involved in both types of decisions, 1 if they are involved in one type of decision or 2 if they are involved in both types of decisions. Women with a total score of 0 are said to have a low level, 1 to have a medium level, and 2 to have a high level of economic autonomy. The reference category is the low level.

The definition of work used in this study is to work or to help earn income for at least for one hour continuously during the seven days before the survey, or if they did not work during the seven days before the survey, they had a permanent job but did not work due to leave, illness, travel, or other temporary reasons. Work status is divided into three categories: paid work, unpaid work, and not working. Furthermore, this study uses several socio-demographic variables as control variables, such as place of residence, economic status, age, education, first marital age, husband's work status, the presence of children aged $0-5$ years, and husband's education. The multinomial logistic regression model equation in this study is:

$$
\begin{aligned}
& \text { Auto }=\alpha_{0}+\alpha_{1} \text { Work }+\sum_{i=1}^{I} \gamma_{\mathrm{i}} X_{1 \mathrm{i}}+\varepsilon_{i} \\
& \text { Work }=\beta_{0}+\beta_{1} \text { Auto }+\sum_{h=1}^{H} \delta_{h} X_{2 \mathbf{h}}+\varepsilon_{i}
\end{aligned}
$$

Equation 1 shows the effect of work status on autonomy and equation 2 shows how autonomy influences work status. $X_{1 i}$ is the control variable vector for autonomy consisting of residence status, economic status, age, age squared, age of first marital, 
education, and husband's education. $X_{2 h}$ is the control variable vector for work status consisting of residence status, presence of child aged 0-5 years, husband's work status, economic status, age, age squared, and education.

\section{Findings}

This study found that the relationship between work status and autonomy depends on work characteristic. Paid work status has strong, positive and robust interplay relationship with economic autonomy.

Compared to non-working married women, those who do paid work are more likely to have higher economic autonomy level. In contrast, compared to women with low level of economic autonomy, those with higher level of economic autonomy are also more likely to do paid work rather than not working. This indicates that women's contribution family income increases her autonomy to allocate household finance [3]. Women with higher level of economic autonomy will be more likely to select a paid work because they already have greater social and economic independence [12].

Unpaid work has insignificant influence on both levels of economic autonomy, and conversely. It is concluded that there is no difference in economic autonomy level between those who work unpaid and those who do not work.

Age, age at first marriage, and education have significant influence on greater likelihood in higher levels of economic autonomy. However, the influence of age on the level of autonomy has an inverse " $U$ " relationship with its peak at age 66 years for non-economic autonomy and 34 years for economic autonomy. Residing in the city has no influence on the high level of economic autonomy and economic status has no influence on economic autonomy level. In addition, all other variables have significant influence on economic autonomy levels.

Table 1. Odds Ratio of Work Status to Autonomy

\begin{tabular}{lcc}
\hline \multicolumn{1}{c}{ Characteristic } & High & Medium \\
\hline Intercept & & \\
Work Status & & \\
$\quad$ Paid Work & $1.1166^{* *}$ & $1.2055^{* * *}$ \\
$\quad$ Unpaid Work & 1.0904 & 1.0971 \\
$\quad$ Not Working (Ref) & & \\
Residence & & \\
$\quad$ Urban & 0.9794 & $1.1613^{* *}$ \\
$\quad$ Rural (Ref) & & \\
Economic Status & & \\
$\quad$ Upper Class & 0.9075 & 1.0263 \\
$\quad$ Middle Class & $0.9027^{*}$ & 0.9386 \\
$\quad$ Lower Class (Ref) & & \\
Age & $1.0905^{* *}$ & $1.0554^{* *}$ \\
Age Squared & $0.9987^{* * *}$ & $0.9991^{* *}$ \\
First Marital Age & $0.9899^{*}$ & $0.9887^{*}$ \\
Education & $1.0698^{* * *}$ & $1.0408^{* * *}$ \\
Husband's Education & $0.9847^{* *}$ & $0.9798^{* *}$ \\
\hline
\end{tabular}


Table 2. Odds Ratio of Autonomy toward Work Status

\begin{tabular}{|c|c|c|}
\hline Characteristic & $\begin{array}{c}\text { Paid } \\
\text { Work }\end{array}$ & $\begin{array}{c}\text { Unpaid } \\
\text { Work }\end{array}$ \\
\hline \multicolumn{3}{|l|}{$\begin{array}{l}\text { Intercept } \\
\text { Autonomy 1) }\end{array}$} \\
\hline $\begin{array}{l}\text { High } \\
\text { Medium } \\
\text { Low }(\text { Ref })\end{array}$ & $\begin{array}{c}1.1167 * * \\
1.1956 * * *\end{array}$ & $\begin{array}{l}1.0929 \\
1.1173\end{array}$ \\
\hline $\begin{array}{l}\text { Residence } \\
\text { Urban } \\
\text { Rural (Ref) }\end{array}$ & $0.8605 * * *$ & $0.3102 * * *$ \\
\hline $\begin{array}{l}\text { Presence of } \\
\text { child 0-5 } \\
\text { years }\end{array}$ & & \\
\hline $\begin{array}{l}\text { Yes } \\
\text { No (Ref) }\end{array}$ & $0.5158 * * *$ & $0.6019 * * *$ \\
\hline $\begin{array}{l}\text { Husband's } \\
\text { Work Status }\end{array}$ & & \\
\hline $\begin{array}{l}\text { Working } \\
\text { Not Working } \\
(\text { Ref) }\end{array}$ & $0.8232 * *$ & $1.6564 * * *$ \\
\hline
\end{tabular}

Economic

Status

Upper Class $\quad 1.0175 \quad 0.8805^{* *}$

Middle

Class

$0.9994 \quad 0.7777 * * *$

Lower

Class (Ref)

\begin{tabular}{lll} 
Age & $1.2001 * * *$ & $1.1995 * * *$ \\
Age Squared & $0.9977 * * *$ & $0.9977 * * *$ \\
Education & $1.0632 * * *$ & $1.0632 * * *$ \\
\hline
\end{tabular}

Note:

p-value: $* * *=\mathrm{p} \leq 0.01 ; * *=\mathrm{p} \leq 0.05 ; *=\mathrm{p} \leq 0.01$

\section{Conclusions}

The main conclusion that can be drawn is that work status and married women's household autonomy level mutually affect each other for all types of autonomy. Paid work status and economic autonomy have significant influence on each other. Paid women workers are more likely to possess high and medium levels of economic autonomy. In contrast, women with a high and a medium level of economic autonomy are also more likely to work for pay. Paid work status and non-economic autonomy have no significant influence on each other.

The presence of a significant mutually influential relationship between paid work status and the economic autonomy of married women in the household may imply that helping married women to stay at work or have paid work is beneficial to or increases her household autonomy. In contrast, ensuring that women have high household autonomy may help to increase married women's participation in paid work. In general, economic 
autonomy is important for married women because they are more able to ensure the welfare of their family with the resources that they own.

\section{References}

1. A.D. Astuti, E.S. Indrawati, and T.P.Astuti, Hubungan antara kemandirian dengan sikap terhadap kekerasan suami pada istri yang bekerja di Kelurahan Sampangan Kec. Gajah Mungkur Kota Semarang [Relationship between independence with attitudes toward husband abuse on wives who work in Kelurahan Sampangan Kec. Gajah Mungkur Kota Semarang], J. Psi, 3, 1 (2006)

2. A. Malhotra and M. Mather, "Do schooling and work empower women in developing countries? Gender and domestic decisions in Sri Lanka”, Sociol Forum, 12, 4 (1997)

3. A. Rammohan, and M. Johar, "The determinants of married women's autonomy in Indonesia”, Fem Econ, 15, 4 (2009)

4. B. Anwar, M. Shoaib, and S. Javed, "Women's autonomy and their role in decision making at household level: a case of rural Sialkot, Pakistan”, World Appl Sci J, 23, 1 (2013)

5. B.S. West, Does Employment Empower Women? An Analysis of Employment and Women's Empowerment in India (Thesis, Cornell University) (2006)

6. D. H. Susilastuti, D. H., Women's education, work and autonomy: an Egyptian case (Dissertation, The Florida State University) (2003)

7. D.R. Acharya, J.S. Bell, P. Simkhada, E.R. Van Teijlingen, and P.R. Regmi., "Women's autonomy in household decision-making: a demographic study in Nepal", Reprod Health, 7, 1 (2010)

8. G. Friedemann-Sánchez, "Assets in intrahousehold bargaining among women workers in Colombia's cut-flower industry”, Fem Econ, 12, 1-2 (2006)

9. L.C. Gates, "The strategic uses of gender in household negotiations: women workers on Mexico's northern border", BLAR, 21, 4 (2002)

10. R. Tfaily, "Do women with higher autonomy have lower fertility? Evidence from Malaysia, the Philippines, and Thailand", Genus, 60, 2 (2004)

11. S.J. Jejeebhoy and Z.A. Sathar, "Women's autonomy in India and Pakistan: the influence of religion and region", Popul Dev Rev, 27, 4 (2001)

12. S. Schaner and S. Das, "Female labor force participation in Asia: Indonesia country study”, ADB Economic Working Paper Series, 474. (2016)

13. S. Yu and J.R. Behrman, Childhood Immunization in India: Roles of Family Structure, Women's Autonomy, and Village Health Service Provision (Dissertation, University of Pennsylvanian) (2004)

14. T. Dyson and M. Moore, M., (1983), "On kinship structure, female autonomy, and demographic behavior in India”, Popul Dev Rev, 9, 1 (1983)

15. T.Varghese, "Women empowerment in Oman: a study based on women empowerment index”, Far East J Psychol Bus, 2, 2 (2011)

16. M. Do and N. Kurimoto, (2012), “Women's empowerment and choice of contraceptive methods in selected African countries". International Perspectives on Sexual and Reproductive Health, 38, 1, pp. 23-33.

17. M. Saputra, Faktor yang mempengaruhi otonomi Perempuan dalam pengambilan keputusan rumah tangga [Factors Affecting Women's Autonomy in Household Decision Making] (Thesis, Universitas Indonesia). (2003)

18. U.D. Uphadyay and D. Karasek, “Women's empowerment and ideal family size: an examination of DHS empowerment measures in sub Saharan Africa”, IPSRH, 38, 2 (2012) 